\title{
Potential Therapeutic Effects of Beet Root (Beta Vulgaris, L.) Pomace on Nephropathy Diabetic Rats
}

\author{
Naglaa A. El-Sheikh ${ }^{1}$, Amal N. Z. Nasef ${ }^{1}$ and Nafisa Y. Othman ${ }^{1}$
}

\begin{abstract}
Beet root possess widespread use in many traditional dishes, whereas its consumption has many highly health and therapeutic benefits to a human body attributed to its high content of phytochemical compounds and high antioxidant properties. The objectives of this study was to assess the potential therapeutic effects of beet root pomace powder (BRPP) on nephropathy induced by gentamicin in diabetic rats and study its application in cakes to utilization of it. Thirty adult male albino rats were randomly divided into two main groups and fed on standard diet. Group I: negative control (6 rats) and group II: nephropathy diabetic rats (24 rats) were given a single dose via intraperitoneal injection of $65 \mathrm{mg} / \mathrm{kg}$ body weight of streptozotocin (STZ). Then, Nephropathy was induced in diabetic rats via intraperitoneally injection daily of gentamicin (GM) $85 \mathrm{mg} / \mathrm{kg}$ body weight for 8 days. Nephropathy diabetic rats group were divided into four subgroups (6 rats each) as follow: First (positive control group), second, third and fourth group received standard diet $+2.5,5$ and $7.5 \%$ of dried BRPP, respectively for 60 days. The results showed that BRPP contained $(416.2 \mathrm{mg}$ gallic acid/100 g) total phenolics, $(31.3 \mathrm{mg}$ catchin $/ 100 \mathrm{~g})$ flavonoids, $(29.2 \mathrm{mg} / 100 \mathrm{~g}) \boldsymbol{\beta}$. carotene, $(2.91 \mathrm{mg} / 100 \mathrm{~g})$ ascorbic acid, (166.5 $\mathrm{mg} / 100 \mathrm{~g})$ betalain and had $(42.87 \%)$ of antioxidant activity. Injection the rats with streptozotocin and gentamicin resulted in elevation in blood and urine glucose levels, lipid profile, kidney functions in the serum and MDA levels with a reduction in the activity of GSH.px, SOD and CAT in kidney tissues and serum insulin levels. Moreover, feeding nephropathy diabetic rats on a daily diet containing BRPP at 5 and $7.5 \%$ of standard diet for 60 days produced a marked reduction in the serum levels of blood and urine glucose, lipid profile, kidney function and MDA levels as well as elevation in the activity of GSH.px, SOD and CAT and serum insulin levels compared to the positive control group. Supplemented rats diet with $7.5 \%$ of BRPP was more effective in improving the previous parameters. Sensory evaluation of cakes prepared with $7.5 \%$ of BRPP showed the better properties in appearance, taste, texture, compressibility, colour and over all acceptability compared with the control and cakes prepared with 2.5 and $5 \%$ of BRPP. The study concluded that BRPP has hypoglycemic potent effects and improve renal damage induced by gentamicin in diabetic rats. So, it is advice to add BRPP to bakery products and consume daily for kidney patients.
\end{abstract}

Keywords: Beet root pomace, nephropathy diabetic rats, streptozotocin, gentamicin.

\section{INTRODUCTION}

Diabetes mellitus (DM) is a noninfectious chronic metabolic disease characterized by chronic hyperglycemia with disturbance in the metabolism of carbohydrates, protein and fat induced lack of insulin secretion by the pancreatic $\beta$ - cells or decreased sensitivity of the target tissues to insulin (WHO, 2016 and Omolaoye et al., 2018). Chronic hyperglycemia associated with high morbidity and mortality due to progressive damage and severe health complications in most tissues and organs, include kidneys, heart, blood vessels, eyes, nerves and skin (Forbes and Cooper, 2013 \& Kahn et al., 2014). Moreover, the progression and aggravation of oxidative stress produced by the impaired metabolism which appears through several mechanisms, such as glucose autoxidation, protein glucation resulting in the development of diabetic complications as nephropathy causing renal failure, retinopathy leading to blindess, neuropathy, macro and microvascular damage and sexual dysfunction (WHO, 2016).

Diabetes produce excess reactive oxygen species which damage the capillaries in the kidney's glomeruli leading to diabetic nephropathy (Kittell, 2012). Also, the kidney is affected by some drugs like antibiotics as gentamicin, which is known for its nephrotoxicity (Nale et al., 2012) and accumulation of gentamicin in renal tubular cells causes apoptosis, necrosis and destruction of cells resulting in renal failure with decreased in glomerular filtration rate (Dontabhaktuni et al., 2016 and Palm et al., 2016).

Hromi -Fiedler et al. (2016) showed that diets rich in vegetables and fruits decrease risks of chronic disease. Beet root (Beta vulgaris L.) has widespread use in traditional Arab medicine for the treatment many of diseases (Vali et al., 2007). Consumption of beet root is associated with numerous health and therapeutic benefits due to its high content of phytochemical compounds and antioxidant properties (Lidder and Webb, 2013 \& Panghal et al., 2017). Beet root contain high amounts of phenolic compounds, flavonoids,

DOI: 10.21608/ASEJAIQJSAE.2019.67106

Dep. of Nutrition \& Food Science, Faculty of Home Economics,

Menoufia University, Shibin El-Kom, Egypt

naglaa.Ali45@yahoo.com

Received October 18, 2019, Accepted December 25, 2019 
carotenoids and betalains, all of which have strong antioxidant and free radical scavenging activities (Sacan and Yanardag, 2010 \& Panghal et al., 2017). Beet root possess hypoglycemic activity by increasing insulin sensitivity and lowering the activity of metabolic enzymes (Murthy and Manchali, 2012 \& Indumathi et al., 2017). As well as previous studies have indicated that red beet root can be used for therapy of renal disorders, where it alleviates renal disfunction and oxidative damage (EL Gamal et al., 2014 and Hassan et al., 2018).

Beet root pomace as waste after the processing of beet root for juice, has a problem of its dispasal and usually used as an animal feed. Because of beet root pomace has been considered as good source of bioactive compounds, phenolics, betalains, soluble dietary fiber and antioxidant activity and so it could be used as functional food (Canadanovi- Brunet et al., 2011 and Vulic et al., 2014) through the use of beet root pomace as an ingredient in bakery products and antioxidants from waste products can be used for protection against the oxidative stress and increasing the constancy of foods by preventing lipid peroxidation in living systems (Makris et al., 2007).

Therefore, the objective of this study was to assess the potential therapeutic effects of beet root pomace powder on nephropathy induced by gentamicin in diabetic rats and study its application in cakes as a functional products.

\section{MATERIALS AND METHODS}

\section{Materials:}

\section{Beet root}

Beet root (Beta vulgaris, L.) was purchased from the local market of Shiben El-Kom, City, Menoufia, Egypt.

\section{Chemicals}

Gentamicin (GM) sulfate was obtained from Memphis Company, For Pharm. \& Chem. Ind. -Cairo -A.R.E. Streptozotocin (STZ) was obtained from Sigma-Aldrich Inc. (St. Louis, Mo, USA) and used for inducing diabetes mellitus in rats. Kits for estimating biochemical analysis were purchased from Alkan Medical Company, El-Doky, Giza, Egypt. Malondialdehyde (MDA), catalase (CAT), glutathione peroxidase (GSH.Px) and superoxide dismutase (SOD) activity Kits were obtained from Biodiagnostic Company, El-Doky, Giza, Egypt.

\section{Animals}

Thirty adult male albino rats, Sprague Drawley stain, weighing $(180 \pm 3 \mathrm{~g})$ were obtained from Medical Insects Research Institute, El-Doky, Giza, Egypt. Rats were housed individually in well aerated cages under hygienic laboratory conditions in Biological Laboratory, Faculty of Home Economics, Department of Nutrition and Food science, Shibin El-kom, Menoufia, Egypt and fed standard diet according to AIN-93 guidelines (Reeves et al., 1993) and consisted of casein (12\%), corn oil $(10 \%)$, cellulose $(5 \%)$, salt mixture $(4 \%)$, vitamin mixture $(1 \%)$ and starch $(68 \%)$ for 7 days as an adaptation period.

\section{Methods:}

\section{Preparation of dried beet root pomace powder}

Beet root pomace as a waste during the preparation of beet root juice was dried in Alab Tech oven under vacuum (Model No. Lvo-2040-Korea) at $50^{\circ} \mathrm{C}$. Then it was ground in an electric mill and passed through 80 mesh sieves (British standard screen). The fine powder was kept in polyethylene bags and stored at $-18^{\circ} \mathrm{C}$ until used.

Determination of total phenolics, total flavonoids, 及.carotene, ascorbic acid, betalain and antioxidant activity of beet root pomace powder

The total phenolics, total flavonoids and $\beta$.carotene contents of beet root pomace powder were determined according to the methods of Kaškonienè et al. (2009), Franke et al. (2004) \& Nagata and Yamashita (1992), respectively. Ascorbic acid and betalain were determined according to the methods described by Mazumdar and Majumder (2003) and Castellar et al. (2003), respectively. Antioxidant activity of beet root pomace powder was determined by 2, 2 diphenyl-1picrylhydrazyl (DPPH) according to Yang et al. (2006).

\section{Experimental design}

Rats were randomly divided into two main groups. The first group, normal control $(n=6)$. The second group: nephropathy diabetic rats $(n=24)$ were given a single dose via intraperitoneal injection of $65 \mathrm{mg} / \mathrm{kg}$ body weight of streptozotocin (STZ) dissolved in a freshly prepared $0.01 \mathrm{M}$ citrate buffer ( $\mathrm{PH}$ 4.5) according to Yanardag et al. (2003). Diabetes was identified by polydipsia, poly-urea (visual observations) and measuring fasting blood glucose level after $72 \mathrm{~h}$ of injection of STZ. Rats with a fasting blood glucose level above $200 \mathrm{mg} / \mathrm{dl}$ were considered diabetic and were used in this study. Then, Nephropathy was induced in diabetic rats via intraperitoneally injection daily of gentamicin (GM) $85 \mathrm{mg} / \mathrm{kg}$ body weight for 8 days as described by Jeyanthi and Subramanian (2009). Nephropathy diabetic rats group were divided into four subgroups (6 rats each) as follows: First (positive control group), second, third and fourth group received standard diet $+2.5,5$ and $7.5 \%$ of dried beet BRPP, respectively for 60 days. At the end of experimental period (60 day), rats were anesthetized with diethyl 
ether after fasting for $12 \mathrm{~h}$ and blood samples were collected from the hepatic portal vein and centrifuged to obtain serum which was kept frozen until analysis. The kidneys were removed and washed in saline solution then saved in formalin solution (10\% v/v) according to the methods described by Drury and Wallington, (1980).

\section{Biochemical analysis}

Glucose in blood and urine was estimated according to Rojas et al. (1999) \& Hugget and Nixon (1957), respectively. Serum insulin level was assayed with a Rat insulin ELISA kit. Insulin sensitivity from the final fasting insulin and glucose values was estimated by the Homeostasis model assessment of insulin resistance (HOMA-IR) according to the following formula: [fasting glucose $(\mathrm{mM}) \times$ fasting insulin $(\mathrm{mUI} / \mathrm{L})] / 22.5$ (Cordero-Herrera et al., 2015). Urea, creatinine and uric acid levels were estimated in serum using commercial kits according to Trinder (1969) \& Tietz (1986) and Fossati et al. (1980), respectively. Serum total protein was determined by the method of Doumas (1975). Albumin and globulin levels were estimated spectrophotometrically using commercial kits according to Tietz (1994). BUN is more easily measured than urea and is used as an index of blood urea level (Philip, 1994). Blood Urea Nitrogen $(B U N)=28 / 60 \times$ serum Urea in $\mathrm{mg} / \mathrm{dl}$. Cholesterol, triglycerides and high-density lipoprotein (HDL.c) were determined according to Allain (1974) \& Fossati and Prencipe (1982) and Burstein et al. (1980), respectively. Low density lipoprotein (LDL.c) and very low-density lipoprotein (VLDL.c) were calculated according to the methods of Lee and Nieman, (1996) as follows: VLDL.c $(\mathrm{mg} / \mathrm{dl})=$ Triglycerides $/ 5$, LDL.c $(\mathrm{mg} / \mathrm{dl})=$ Total cholesterol - (HDL.c + VLDL.c). Malondialdehyde (MDA) was estimated in kidney tissues according to the method of Lefevre et al. (1998). Catalase (CAT), Glutathione peroxidase (GSH.Px) and Superoxide dismutase (SOD) activities were assayed using the methods described by Aebi (1984); Necheles et al. (1968) and Masayasu and Hiroshi (1979), respectively.

\section{Technological methods \\ Preparation of cake}

Cake were prepared according to the formula of Khalil (1998) using the following recipe: $259 \mathrm{~g}$ wheat flour (72\%), $24 \mathrm{~g}$ margarine, $24 \mathrm{~g}$ sugar,13.55g whole egg, $0.45 \mathrm{~g}$ backing power, $10 \mathrm{~g}$ skim milk and $30 \mathrm{~g}$ cocoa to prepare the control cake, Sugar and margarine were creamed for $3 \mathrm{~min}$ at speed 5 . The whole eggs were added and mixed in at the same speed for $2 \mathrm{~min}$. The flour, backing powder, cocoa and skim milk were added and the batter was minced for 4 min at speed 6 . After scraping down the bowl the batter was mixed for an additional $1 \mathrm{~min}$ at speed 6 , to prepare cake by replacing different levels of beet root pomace powder, the wheat flour in the formula was replaced with either 2.5, 5 and $7.5 \%$ of BRPP. The same order of mixing as described for the control was followed. Cake batters were baked at $220^{\circ} \mathrm{C}$ for $30 \mathrm{~min}$ in an electric oven (8605 Universal-Egypt) then removed from the pans and cooled at room temperature $\left(25^{\circ} \mathrm{C}\right)$ for $60 \mathrm{~min}$.

\section{Sensory evaluation}

Sensory evaluation of cake samples was performed using fifteen of staff members from Department of Nutrition and Food Science, Faculty of Home Economic, Menoufia University according to Sudha et al. (2007). The panelists were asked to evaluate appearance, taste, flavour, texture, compressibility, colour and overall acceptability of the cakes. A rating scale of $1-10$ points was used $(10=$ excellent, $9=$ like extremely, $8=$ like very much, $7=$ like moderately, $6=$ like slightly, $5=$ neither like nor dislike, $4=$ dislike slightly, $3=$ dislike moderately, $2=$ dislike very much and $1=$ dislike extremely). Accuracy and precision were evaluated statistically. Cake was evaluated, $2 \mathrm{~h}$ after baking. Panelists evaluated one piece of different cake systems which were offered at the same time in an open area at room temperature $\left(25^{\circ} \mathrm{C}\right)$ without special lighting. Water was provided for rinsing purposes.

\section{Statistical analysis}

The results were expressed as the mean $\pm \mathrm{SD}$. The data for multiple variable comparisons were analyzed by one-way analysis of variance (ANOVA). For the comparison of significance between groups, Duncan's test was used as a post hoc test according to the statistical package program (Artimage and Berry, 1987).

\section{RESULTS AND DISCUSSION}

Table (1) shows total phenolics, flavonoids, B.carotene, ascorbic acid, betalain and antioxidant activity of beet root pomace powder. Beet root pomace powder contained $416.2 \mathrm{mg}$ gallic acid / $100 \mathrm{~g}$ total phenolics, $31.3 \mathrm{mg}$ catchin / $100 \mathrm{~g}$ flavonoids, $29.2 \mathrm{mg} /$ $100 \mathrm{~g}, \beta$.carotene, $2.91 \mathrm{mg} / 100 \mathrm{~g}$ ascorbic acid, 166.5 $\mathrm{mg} / 100 \mathrm{~g}$ betalain and $42.87 \%$ antioxidant activity. These results are in agreement with Vulic' et al. (2012) found that the phenolic content of beet root pomace varied from 1.87 to $11.98 \mathrm{mg}$ gallic acid equivalents (GAE)/g dry weight, flavonoids $37.96 \mathrm{mg} / 100 \mathrm{~g}$ of dry weight and the betalain varied from 0.75 to $3.75 \mathrm{mg} / \mathrm{g}$ of dry weight. Furthermore, Čanadanović-Brunet et al. (2011) reported that ethanol, acetone, and water extracts of beet root pomace had $376.4,343.8$ and $218.3 \mathrm{mg}$ GAE/g of dry extract phenols, 253.5, 269.7 and 200.5 $\mathrm{mg}$ (rutin equivalents RE)/g of dry extract flavonoids, $24.18,22.65$ and $18.78 \mathrm{mg} / \mathrm{g}$ of dry extract betacyanins and $17.67,11.19$ and $22.90 \mathrm{mg} / \mathrm{g}$ of dry extract 
betaxanthins and showed that beet root pomace possess radical scavenging activity towards stable DPPH and highly reactive hydroxyl and superoxide anion radicals. This antiradical activity of beet root pomace may due to its content of total phenolics, flavanoids, anthocyanin and betaxanthin.

Table 1. Total phenolics, flavonoids, $\beta$.carotene, ascorbic acid, betalain and antioxidant activity of BRPP

\begin{tabular}{lc}
\hline \multicolumn{1}{c}{ Parameter } & BRPP \\
\hline Total phenolics (mg gallic & $416.2 \pm 1.51$ \\
acid/100g) & \\
Flavonoids (mg catechin/100 g) & $31.3 \pm 1.5$ \\
ß.carotene $(\mathrm{mg} / 100 \mathrm{~g})$ & $29.2 \pm 1.01$ \\
Ascorbic acid $(\mathrm{mg} / 100 \mathrm{~g})$ & $2.91 \pm 0.55$ \\
Betalain $(\mathrm{mg} / 100 \mathrm{~g})$ & $166.5 \pm 1.5$ \\
Antioxidant activity $(\%)$ & 42.87 \\
\hline
\end{tabular}

Each value in the Table is the mean \pm standard deviation of three replicates.

The effect of beet root pomace powder on glucose in blood and urine and insulin in nephropathy diabetic rats are presented in Table (2). The nephropathy diabetic rats had higher $(\mathrm{P} \leq 0.05)$ blood glucose level than those in the normal control during the experimental period. Wei et al. (2003) found that Streptozotocin (STZ) had a high affinity for binding the glucose receptors present on the pancreatic $\beta$-cells, its ingestion relish the cytotoxic effect upon these cells and lead to dysfunction or cell death. This subsequently leads to alteration of insulin levels and blood glucose concentrations. The blood glucose level was not affected along the experimental period for the normal and the positive control rats which fed on the basal diet.

At the beginning of the experimental period ( $0^{\text {th }}$ day) non- significant difference in blood glucose level was observed between the positive control rats and nephropathy diabetic rats fed on BRPP diets $(2.5,5$ and $7.5 \%$ ). However, the blood glucose level of nephropathy diabetic rats fed on BRPP diets was significantly decreased by increasing the experimental period and BRPP levels. At the end of the experimental period $\left(60^{\text {th }}\right.$ day), blood glucose levels in nephropathy diabetic rats fed on 2.5, 5 and $7.5 \%$ of BRPP reduced by 16.45 , 32.90 and $44.78 \%$ respectively compared to the beginning day. The highest reduction in blood glucose level was found in nephropathy diabetic rats fed on $7.5 \%$ of beet root pomace powder. This hypoglycemic effect of beet root pomace powder could be attributed to its content of total phenolics, flavonoids and betalains.

Table 2. Effect of BRPP on glucose in blood and urine and insulin of nephropathy diabetic rats

\begin{tabular}{|c|c|c|c|c|c|}
\hline \multirow[b]{3}{*}{ Parameter } & \multirow{3}{*}{$\begin{array}{l}\text { Normal } \\
\text { Control }\end{array}$} & \multicolumn{4}{|c|}{ Nephropathy Diabetic Rats } \\
\hline & & \multirow{2}{*}{$\begin{array}{l}\text { Positive } \\
\text { Control }\end{array}$} & \multicolumn{3}{|c|}{ BRPP } \\
\hline & & & $2.5 \%$ & $5 \%$ & $7.5 \%$ \\
\hline $\begin{array}{l}\text { Blood Glucose }(\mathrm{mg} / \mathrm{dl}) \\
0^{\text {th }} \text { Day }\end{array}$ & $97^{\mathrm{Ab}} \pm 2.16$ & $231^{\mathrm{Aa}} \pm 0.82$ & $231^{\mathrm{Aa}} \pm 1.96$ & $231^{\mathrm{Aa}} \pm 1.63$ & $230^{\mathrm{Aa}} \pm 1.82$ \\
\hline $30^{\text {th }}$ Day & $97^{\mathrm{Ad}} \pm 2.16$ & $231^{\mathrm{Aa}} \pm 0.82$ & $229^{\mathrm{Aa}} \pm 2.16$ & $218^{\mathrm{Bb}} \pm 2.82$ & $200^{\mathrm{Bc}} \pm 1.55$ \\
\hline $60^{\text {th }}$ Day & $97^{\mathrm{Ae}} \pm 2.16$ & $231^{\mathrm{Aa}} \pm 0.82$ & $193^{\mathrm{Bb}} \pm 2.45$ & $155^{\mathrm{Cc}} \pm 1.41$ & $127^{\mathrm{Cd}} \pm 2.08$ \\
\hline$\%$ Lowering of Blood Glucose Level & 0.0 & 0.0 & 16.45 & 32.90 & 44.78 \\
\hline $\begin{array}{l}\text { Urine Glucose }(\mathrm{mmol} / \mathrm{l}) \\
0^{\text {th }} \text { Day }\end{array}$ & 0.0 & $59^{\mathrm{Aa}} \pm 1.63$ & $58^{\mathrm{Aa}} \pm 1.63$ & $58^{\mathrm{Aa}_{ \pm}} 2.08$ & $59^{\mathrm{Aa}} \pm 2.36$ \\
\hline $30^{\text {th }}$ Day & 0.0 & $59^{\mathrm{Aa}} \pm 1.63$ & $57^{\mathrm{Aa}} \pm 2.45$ & $45^{\mathrm{Bb}} \pm 2.58$ & $27^{\mathrm{Bc}} \pm 1.83$ \\
\hline $60^{\text {th }}$ Day & 0.0 & $59^{\mathrm{Aa}} \pm 1.63$ & $47^{\mathrm{Bb}} \pm 1.41$ & $34^{\mathrm{Cc}} \pm 1.38$ & $18^{\mathrm{Cd}} \pm 2.16$ \\
\hline$\%$ Lowering of Urine Glucose Level & 0.0 & 0.0 & 18.97 & 41.38 & 69.49 \\
\hline $\begin{array}{l}\text { Serum Insulin (ng/mg) } \\
0^{\text {th }} \text { Day }\end{array}$ & $3^{\mathrm{Aa}} \pm 0.29$ & $0.50^{\mathrm{Ab}} \pm 0.03$ & $0.50^{\mathrm{Bb}} \pm 0.02$ & $0.48^{\mathrm{Cb}} \pm 0.01$ & $0.50^{\mathrm{Cb}} \pm 0.01$ \\
\hline $30^{\text {th }}$ Day & $3^{\mathrm{Aa}} \pm 0.29$ & $0.50^{\mathrm{Ac}} \pm 0.03$ & $0.51^{\mathrm{Bc}} \pm 0.02$ & $0.62^{\mathrm{Bbc}} \pm 0.01$ & $0.82^{\mathrm{Bb}} \pm 0.02$ \\
\hline $60^{\text {th }}$ Day & $3^{\mathrm{Aa}} \pm 0.29$ & $0.50^{\mathrm{Ad}} \pm 0.03$ & $0.60^{\text {Acd }} \pm 0.10$ & $0.77^{A c} \pm 0.14$ & $1.10^{\mathrm{Ab}} \pm 0.08$ \\
\hline$\%$ Change of Insulin & 0.0 & 0.0 & 20 & 60.42 & 120 \\
\hline Insulin Sensitivity Index (HOMA-IR) & $29.95^{\mathrm{a}} \pm 2.48$ & $11.89^{\mathrm{c}} \pm 0.56$ & $11.92^{\mathrm{c}} \pm 1.92$ & $12.28^{\mathrm{bc}} \pm 1.37$ & $14.38^{\mathrm{b}} \pm 1.03$ \\
\hline
\end{tabular}

Data are expressed as mean \pm SD. Values within a row having different superscripts are significantly different $(\mathrm{p} \leq 0.05)$; where the small letters indicate significant among dietary treatment groups as indicated by one-way ANOVA followed by Duncan's multiple range test $(a>b>c>d>e)$, while capital letters referred to statistical differences among experimental periods, HOMAIR. 
These results are similar to the results obtained by Olumese and Oboh, (2017) who found that administered rats with 500 and $1000 \mathrm{mg} / \mathrm{kg}$ of beet root aqueous extract for 28 days resulted in reduction in blood glucose levels. This reduction could be due to the presence of bioactive compounds in the extract which potentiated the observed hypoglycemic effect. Also, Abdel-Monem et al. (2014) showed that the aqueous and ethyl acetate extracts of beet root $(400 \mathrm{mg} / \mathrm{kg})$ reduced blood glucose levels in diabetic rats.From the results of Table (2) it can be observed that nephropathy diabetic untreated rats (positive control) were highly glycosuric, while glucose was not noted in the urine of normal rats. At the $30^{\text {th }}$ and $60^{\text {th }}$ day of the experimental period, the urine glucose level was significantly decreased in nephropathy diabetic rats fed on BRPP by increasing the level of BRPP in the rat diets as compared to the positive control rats. Furthermore, at the $60^{\text {th }}$ day of the experimental period, feeding on 2.5, 5 and $7.5 \%$ of beet root pomace powder led to a significant decline in urine glucose level by $18.97,41.88$ and $69.49 \%$, respectively when compared with the $0^{\text {th }}$ day. Moreover, BRPP at level $7.5 \%$ was identified as the most effective in lowering urine glucose level. These results are in accordance with that reported by GezginciOktayoglu et al. (2014) and Sacan and Yanardag (2010) who found that beet root has antioxidant and anti-diabetic properties in addition to its protective effect against hyperglycemia-induced tissue damage. Also, Vulic' et al. (2012) indicated that the pomace extract obtained from Egyptian beet root, contained high amounts of bioactive phenolics and betalains that possessed antioxidant, anti-diabetic and antiproliferative activities.

On the other hand, nephropathy diabetic untreated rats (positive control) and nephropathy diabetic rats fed on BRPP diets had lower serum insulin level than the normal control rats during the experimental period. However, the serum insulin level was significantly $(p \leq 0.05)$ increased by increasing the experimental period and beet root pomace powder levels. The results are compatible with Panda and Kar (2007) who reported that the anti- diabetic properties of red beet flavonoids resulted in increased pancreatic insulin. Treatment with red beet did not influence the plasma insulin level, but decreased glycemia by $22 \%$ while, red beet extracts significantly decreased glycaemia and serum insulin levels by 2.5 fold, suggesting the antidiabetic synergistic activity. A significant increase in serum insulin level was observed in nephropathy diabetic rats fed on 5 and $7.5 \%$ BRPP diets in the $30^{\text {th }}$ day of experimental period, while no significant differences were noted in serum insulin levels between nephropathy diabetic rats fed on 2.5 BRPP and the positive control rats. Moreover, at the $60^{\text {th }}$ day of experimental period serum insulin level increased by 20 , 60.42 and $120 \%$ respectively for the $0^{\text {th }}$ day of experimental period. The achieved results confirmed by Ul- Kabir et al. (2015) reported that treatment of aqueous fraction of beet root extract ameliorated hyperglycemia in diabetic mice due to enhanced glucose- stimulated insulin secretion mediated by acetylcholine and glucagon- like peptide-1 (GLP-1).

Furthermore, nephropathy diabetic rats had significant reduction in insulin sensitivity index values compared to the normal control rats, while feeding nephropathy diabetic rats with 5 and $7.5 \%$ BRPP diets caused a significant elevation in insulin sensitivity index values compared with the positive control rats. As well as, supplementation nephropathy diabetic rats with 7.5\% BRPP was more effective in increasing sensitivity index value than those supplemented with 5\% BRPP. Our results corroborate the findings of Wootton-Beard $e t$ al.(2011) observed that antioxidants, such as flavonoids, betalains and polyphenol in beet root extract improved insulin sensitivity and inhibition of glucose uptake.

The data in Table (3) reflects the effect of beet root pomace powder on kidney function of nephropathy diabetic rats. Levels of urea, creatinine, uric acid and blood urea nitrogen (BUN) in serum were used as biochemical markers to evaluate the renal injury. In diabetes, high glucose level caused kidney damages and impairment in renal function resulting in elevation in the levels of urea, creatinine and uric acid which is considered as markers of renal dysfunction. From the Table it can be observed that serum urea, creatinine, BUN and uric acid levels were significantly higher in the positive control rats than that in the normal control rats, while total protein, albumin and globulin had an opposite trend. This elevation in serum markers of kidney function found to be an indicator of decrease in glomerular filtration rate and tissue injury. This results are compatible with the findings of Jain and Somani (2015) and El- Kashef et al. (2015) found that GM induced nephrotoxicity caused significant increase in serum level urea, creatinine and BUN as compared to un-indicating renal dysfunction. This damaging in glomerular function was accompanied by a reduced excretion of urea and creatinine. Also, this elevation in serum creatinine level in gentamicin group was found to be an indicator of decrease in glomerular filtration rate, whereas the increased serum urea and BUN levels were found to be an indicator of parenchyma tissue injury after tubular necrosis (Sodimbaku et al., 2016). As well 
as, hyperglycemia caused a significant elevation in markers of renal dysfunction (Elizabeth and Harris, 2005).

The data in the same Table showed no significant differences in urea, creatinine, BUN, uric acid, total protein, albumin and globulin levels were observed among the positive control rats and nephropathy diabetic rats supplemented with $2.5 \%$ BRPP. On the other side, supplementation nephropathy diabetic rats with 5 and 7.5\% BRPP led to a significant reduction in levels of urea, creatinine, BUN and uric acid as well as elevation in total protein, albumin and globulin levels compared to nephropathy diabetic rats supplemented with $2.5 \%$ BRPP. These results are concomitant with Hassan et al. (2018) and El- Gamal et al. (2014) reported that red beet root attenuates renal dysfunction and structural damage through the reduction levels of serum kidney markers and oxidative stress on kidneys and suggested that beet root extract has a renal protective potential. Also, Tan et al. (2015) found that betanin spelling have effect on serum markers for kidney acute injuries, including urea, creatinine and uric acid in rats.

Furthermore, supplementation of nephropathy diabetic rats diet with 7.5\% BRPP was more effective in reducing urea, creatinine, BUN and uric acid levels than those supplemented with 5\% BRPP while, nephropathy diabetic rats supplemented with $7.5 \%$ BRPP had a higher total protein, albumin and globulin than those supplemented with 5\% BRPP. This improvement effect in kidney function may be attributed to antioxidant properties and phytoconstituents of beet root pomace. These results confirmed the results of Xu et al. (2016) showed that flavonoids protected against diabetic nephropathy in STZ-induced diabetic mice improving blood urea nitrogen, serum creatinine and urine protein levels as well as kidney tissue damage, with a reduction in mitochondrial damage.

The results inTable (4) shows the effect of beet root pomace powder on serum lipid profile of nephropathy diabetic rats. The results indicated that the levels of serum cholesterol, triglyceride (TG), low density lipoprotein cholesterol (LDL.c) and very low density lipoprotein cholesterol (VLDL.c) significantly increased in nephropathy diabetic rats compared to the normal control rats. But, high density lipoprotein cholesterol (HDL.c) had an opposite trend. This is in agreement with Azab and Algridi (2017) who reported that gentamicin treatment caused significant increases in the serum cholesterol, triglycerides, LDL.c and VLDL.c levels in rats and decreased HDL.c compared to the normal control group. As well as, Haque et al. (2014) found that the levels of serum and plasma total cholesterol, TG, LDL.c and VLDl.c increased in diabetic rats.

Table 3. Effect of BRPP on kidney function of nephropathy Diabetic rats

\begin{tabular}{lccccc} 
& \multirow{2}{*}{ Groups } & Normal & \multicolumn{3}{c}{ Nephropathy Diabetic Rats } \\
\cline { 3 - 6 } Parameter & Control & Positive & \multicolumn{3}{c}{ BRPP } \\
\cline { 3 - 6 } & & Control & $\mathbf{2 . 5 \%}$ & $\mathbf{5 \%}$ \\
\hline Urea $(\mathrm{mg} / \mathrm{dl})$ & $23^{\mathrm{d}} \pm 0.82$ & $51^{\mathrm{a}} \pm 2.22$ & $49^{\mathrm{a}} \pm 2.58$ & $39^{\mathrm{b}} \pm 1.82$ & $33^{\mathrm{c}} \pm 1.28$ \\
Creatinine $(\mathrm{mg} / \mathrm{dl})$ & $0.20^{\mathrm{d}} \pm 0.03$ & $0.93^{\mathrm{a}} \pm 0.29$ & $0.89^{\mathrm{a}} \pm 0.03$ & $0.68^{\mathrm{b}} \pm 0.06$ & $0.43^{\mathrm{c}} \pm 0.03$ \\
BUN (mg/dl) & $11.41^{\mathrm{d}} \pm 0.82$ & $24.57^{\mathrm{a}} \pm 3.32$ & $23.95^{\mathrm{a}} \pm 0.85$ & $20^{\mathrm{b}} \pm 0.82$ & $15.37^{\mathrm{c}} \pm 0.65$ \\
Uric Acid (mg/dl) & $1.84^{\mathrm{d}} \pm 0.25$ & $4^{\mathrm{a}} \pm 0.08$ & $3.85^{\mathrm{a}} \pm 0.06$ & $2.98^{\mathrm{b}} \pm 0.14$ & $2.5^{\mathrm{c}} \pm 0.16$ \\
Total Protein $(\mathrm{mg} / \mathrm{dl})$ & $10.53^{\mathrm{a}} \pm 1.88$ & $4.7^{\mathrm{d}} \pm 0.08$ & $5.1^{\mathrm{d}} \pm 0.37$ & $6.11^{\mathrm{c}} \pm 0.16$ & $7.3^{\mathrm{b}} \pm 0.13$ \\
Albumin $(\mathrm{mg} / \mathrm{dl})$ & $5.53^{\mathrm{a}} \pm 1.73$ & $2.7^{\mathrm{d}} \pm 0.29$ & $3^{\mathrm{d}} \pm 0.22$ & $3.51^{\mathrm{c}} \pm 0.09$ & $4.1^{\mathrm{b}} \pm 0.24$ \\
Globulin $(\mathrm{mg} / \mathrm{dl})$ & $5^{\mathrm{a}} \pm 1.87$ & $2^{\mathrm{d}} \pm 0.41$ & $2.1^{\mathrm{d}} \pm 0.08$ & $2.6^{\mathrm{c}} \pm 0.36$ & $3.2^{\mathrm{b}} \pm 0.24$ \\
\hline
\end{tabular}

Data are expressed as mean $\_$SD. Values within a same row having different superscripts are significantly different $(\mathrm{P} \leq 0.05)$. BUN : Blood Urea Nitrogen.

Table 4. Effect of BRPP on lipid profile of nephropathy Diabetic rats

\begin{tabular}{lccccc} 
& \multirow{2}{*}{ Groups } & Normal & \multicolumn{3}{c}{ Nephropathy Diabetic Rats } \\
\cline { 3 - 6 } Parameter & Control & Positive & \multicolumn{3}{c}{ BRPP } \\
\cline { 3 - 6 } & & Control & $\mathbf{2 . 5 \%}$ & $\mathbf{5 \%}$ \\
\hline Cholesterol $(\mathrm{mg} / \mathrm{dl})$ & $38^{\mathrm{d}} \pm 2.44$ & $71^{\mathrm{a}} \pm 1.41$ & $70^{\mathrm{a}} \pm 3.60$ & $62^{\mathrm{b}} \pm 1.83$ & $51^{\mathrm{c}} \pm 1.38$ \\
Triglyceride $(\mathrm{mg} / \mathrm{dl})$ & $22^{\mathrm{d} \pm 1.29}$ & $43^{\mathrm{a}} \pm 2.94$ & $41^{\mathrm{a}} \pm 2.71$ & $36^{\mathrm{b}} \pm 3.56$ & $32^{\mathrm{c}} \pm 1.41$ \\
HDL-c $(\mathrm{mg} / \mathrm{dl})$ & $28^{\mathrm{a}} \pm 1.29$ & $14^{\mathrm{d}} \pm 1.83$ & $14.6^{\mathrm{d}} \pm 1.41$ & $17.55^{\mathrm{c}} \pm 0.33$ & $20^{\mathrm{b}} \pm 1.41$ \\
LDL-c $(\mathrm{mg} / \mathrm{dl})$ & $5.6^{\mathrm{d}} \pm 1.89$ & $48.4^{\mathrm{a}} \pm 2.55$ & $47.2^{\mathrm{a}} \pm 3.50$ & $37.25^{\mathrm{b}} \pm 1.45$ & $24.6^{\mathrm{c}} \pm 3.17$ \\
VLDL-c $(\mathrm{mg} / \mathrm{dl})$ & $4.4^{\mathrm{d}} \pm 0.26$ & $8.6^{\mathrm{a}} \pm 0.59$ & $8.2^{\mathrm{ab}} \pm 0.54$ & $7.2^{\mathrm{bc}} \pm 0.71$ & $6.4^{\mathrm{c}} \pm 0.28$ \\
\hline
\end{tabular}

Data are expressed as mean +SD. Values within a same row having different superscripts are significantly different $(\mathrm{p} \leq 0.05)$. HDL.c: high density lipoprotein cholesterol, LDL.c: low density lipoprotein cholesterol, VLDL.c: very Low density lipoprotein cholesterol. 
It was mentioned that feeding nephropathy diabetic rats with 5 and $7.5 \%$ BRPP resulted in a decrease in cholesterol, TG, LDL.c and VLDL.c levels and an increase in HDL.c level compared with the positive control rats. However, the levels of cholesterol, TG, HDL.c, LDL.c and VLDL.c in nephropathy diabetic rats which fed on $2.5 \%$ BRPP did not differ from the positive control rats. The present results are in the same trend with Bala et al. (2019) found that supplementation with $5 \mathrm{~g}$ per day of beet root powder for 3 months significantly decreased the serum cholesterol, triglycerides, LDL.c levels and increased the HDL.c level . As the dietary supplementation with $3 \%$ of beet root crisps caused a reduction in serum total cholesterol, triacylglycerols and total cholesterol hepatic levels suggested that the beet root crisps could alleviate metabolic changes in dyslipidemic diet- administered rats (Wroblewska et al., 2011).

Moreover, nephropathy diabetic rats supplemented with 7.5\% BRPP had the highest reduction in the levels of cholesterol, TG and LDL.c and elevation in HDL.c compared to those supplemented with 5\% BRPP, while that the level of VLDL.c in nephropathy diabetic rats supplemented with 5\% BRPP did not differ from nephropathy diabetic rats supplemented with $7.5 \%$ BRPP. These results are in agreement with Singh et al. (2015) who showed that the consumption of beet root lowered total cholesterol, triglycerides, LDL-c levels and increased the levels of HDL-c in humans. Also, Sardi et al. (2009) reported that feeding with $2 \mathrm{~g} / \mathrm{kg}$ of beet root powder for 10 days resulted in significant changes in serum cholesterol levels and reduction of fatty liver symptoms in a chemically induced diabetic animal model. This improvement of serum lipid profile in rats treated with beet root pomace powder may be attributed to betalain and the high polyphenol content of beet root.

Table (5) shows the effect of beet root pomace powder on antioxidant enzymes and MDA in kidney of nephropathy diabetic rats. In biological systems, there is a balance between the production and neutralization of reactive oxygen species (ROS). This balance is maintained by the presence of natural antioxidants and antioxidant enzymes such as catalase and glutathione peroxidase. The enhancement of lipid peroxidation or the decrease of antioxidant protection present in metabolic diseases or bad lifestyle can induce endothelial dysfunction (Lubrano and Balzan, 2015). There were significantly an increase of malonaldehyde (MDA) level and a decrease of catalase (CAT), glutathione peroxidase (GSH.Px) and superoxide dismutase (SOD) activities in the positive control rats comparing to the normal control rats. These results could be due to gentamicin increases the generation of ROS which may reduce the activities of antioxidant enzymes and by depleting intracellular concentrations of GSH during the process of combating oxidative stress, which enhances lipid peroxidation (Rajashkar et al., 2012). Kamel et al. (2015) and Abuelezz et al. (2016) observed that gentamicin caused significant decrease in the activities of renal antioxidant enzymes CAT, GSH.px and SOD coupled with increase in MDA level compared with the normal control rats. Also, Saddala et al. (2013) reported that diabetes mellitus was associated with a free radical induced lipid peroxidation and reduction in antioxidant enzymes activity.

On the other hand, no significant differences were found in the level of MDA and CAT, GSH.Px and SOD activity among nephropathy diabetic rats supplemented with $2.5 \%$ BRPP and the positive control rats, whereas feeding nephropathy diabetic rats with $5 \%$ and $7.5 \%$ BRPP improved the activity of CAT, GSH.Px and SOD as well as the level MDA showed significant decrease as compared with the positive control rats. This positive effect of BRPP may be attributed to its antioxidant and free radical scavenging abilities. These findings are compatible with the findings of Olumese and Oboh (2019) who observed that there are overwhelming significant $(\mathrm{p} \leq 0.05)$ reduction in MDA level in rats administrated with $500 \mathrm{mg} / \mathrm{kg}$ BW of beet root extract. Also, Gezginici-Oktayoglu et al. (2014) showed that beet root extract resulted in reduction the oxidative stress and increased the antioxidant defense by the decreased MDA formation and elevated the activities of CAT, GSH.Px and SOD.

Furthermore, the highest elevation in the activity of CAT, GSH.Px and SOD was observed in nephropathy diabetic rats supplemented with $7.5 \%$ BRPP, while MDA had an opposite trend. These results indicated that the important role of betalains and other phenolic compounds presented in red beet pomace powder in reducing of oxidative damage of lipids and improves antioxidant status. These results confirmed the results of Hassan et al. (2018) reported that beet root has antioxidant activity, which markedly attenuated the oxidative stress induced by GM and inhibited lipid peroxidation and the enhancement of gene expression and activities of antioxidant enzymes. Moreover, Vulić et al. (2012) found that beet root pomace contained high amounts of bioactive phenol and betalain that possessed antioxidant and antiproliferative activities. These results are similar to the results obtained by Liu et al. (2008) reported that beet root pomace possesses appreciable amount of antioxidant compounds or other substances with positive health effects. 
Table 5. Effect of BRPP on antioxidant enzymes and MDA in kidney of nephropathy diabetic rats

\begin{tabular}{lccccc} 
& \multirow{2}{*}{ Groups } & \multirow{4}{c}{ Normal } & \multicolumn{3}{c}{ Nephropathy Diabetic Rats } \\
\cline { 3 - 6 } Parameter & Control & Positive & \multicolumn{3}{c}{ BRPP } \\
\cline { 3 - 5 } & & Control & $\mathbf{2 . 5 \%}$ & $\mathbf{5 \%}$ & $\mathbf{7 . 5 \%}$ \\
\hline MDA (nmol/mg. tit) & $9^{\mathrm{d} \pm 1.59}$ & $29.93^{\mathrm{a}} \pm 4.14$ & $29.33^{\mathrm{a}} \pm 1.53$ & $26.45^{\mathrm{b}} \pm 1.22$ & $15.5^{\mathrm{c}} \pm 1.83$ \\
CAT (ng/mg. tit) & $34.25^{\mathrm{a}} \pm 3.77$ & $14^{\mathrm{d}} \pm 1.41$ & $14.35^{\mathrm{d}} \pm 1.08$ & $17.75^{\mathrm{c}} \pm 1.71$ & $22^{\mathrm{b}} \pm 2.94$ \\
GSH.px. (ng/mg. tit) & $41.6^{\mathrm{a}} \pm 1.66$ & $15.18^{\mathrm{d}} \pm 3.76$ & $15.75^{\mathrm{d}} \pm 2.79$ & $18.75^{\mathrm{c}} \pm 1.29$ & $28.25^{\mathrm{b}} \pm 1.26$ \\
SOD (U/L. tit) & $40.7^{\mathrm{a}} \pm 2.88$ & $9.2^{\mathrm{d}} \pm 2.18$ & $10.5^{\mathrm{d}} \pm 1.29$ & $14.68^{\mathrm{c}} \pm 2.21$ & $28.6^{\mathrm{b}} \pm 1.07$ \\
\hline
\end{tabular}

Data are expressed as mean +SD. Values within a same row having different superscripts are significantly different $(p \leq 0.05)$. MDA: malonaldehyde, CAT: catalase, GSH.Px: glutathione peroxidase, SOD: superoxide dismutase.

Table 6. Sensory evaluation of cake prepared by replacing wheat flour with different levels of BRPP

\begin{tabular}{lcccc}
\hline \multicolumn{1}{c}{ Parameter } & Control & $\mathbf{2 . 5 \%}$ & $\mathbf{5 \%}$ & $\mathbf{7 . 5 \%}$ \\
\hline Appearance & $8.55^{\mathrm{a}} \pm 1.29$ & $8.8^{\mathrm{a}} \pm 1.1$ & $8.7^{\mathrm{a}} \pm 0.8$ & $9.3^{\mathrm{a}} \pm 0.82$ \\
Taste & $9.15^{\mathrm{ab}} \pm 1.50$ & $8^{\mathrm{b}} \pm 1.42$ & $8.65^{\mathrm{ab}} \pm 1.14$ & $9.7^{\mathrm{a}} \pm 1.16$ \\
Flavour & $8.35^{\mathrm{b}} \pm 1.34$ & $8.05^{\mathrm{b}} \pm 0.71$ & $8.15^{\mathrm{b}} \pm 1.03$ & $9.4^{\mathrm{a}} \pm 1.19$ \\
Texture & $8.7^{\mathrm{a}} \pm 1.47$ & $9.5^{\mathrm{a}} \pm 1.36$ & $8.7^{\mathrm{a}} \pm 0.45$ & $8.9^{\mathrm{a}} \pm 1.2$ \\
Compressibility & $9.7^{\mathrm{a}} \pm 0.48$ & $8.85^{\mathrm{b}} \pm 0.88$ & $9.58^{\mathrm{ab}} \pm 0.69$ & $9.1^{\mathrm{a}} \pm 1.05$ \\
Colour & $9.55^{\mathrm{a}} \pm 1.15$ & $8.95^{\mathrm{a}} \pm 1.27$ & $8.75^{\mathrm{a}} \pm 1.33$ & $8.7^{\mathrm{a}} \pm 1.08$ \\
Overall acceptability & $9.3^{\mathrm{a}} \pm 0.67$ & $8.9^{\mathrm{b}} \pm 0.97$ & $9.15^{\mathrm{ab}} \pm 1$ & $9.8^{\mathrm{a}} \pm 0.26$ \\
\hline
\end{tabular}

Data are expressed as mean \pm SD. Values within a same row having different superscripts are significantly different. $(p \leq 0.05)$.

Sensory evaluation of cake prepared by replacing different levels of beet root pomace powder is presented in Table (6). The consumer is a major factor for selecting a product quality are colour, odour, taste and texture (Pereira et al., 2013). No significant differences were observed in appearance, texture and colour between cake prepared with $2.5,5$ and $7.5 \%$ replacement levels BRPP and the control cake. Also, there were no significant differences in taste and overall acceptability among cake prepared with 5 and 7.5\% BRPP and the control cake. The lowest values of taste and overall acceptability were recorded in cake prepared with 5\% BRPP. However, replacement of wheat flour with $7.5 \%$ BRPP produced cake which had the highest taste and overall acceptability. These observations are in accordance with those reported by Huma et al. (2017) who found that the replacement of beet root pomace powder in the respective formulations has no significant effect on the overall acceptability and more acceptable in sensory properties of biscuits.

Furthermore, flavour of cake prepared with 2.5 and $5 \%$ BRPP was not differed from the control cake, while cake prepared by replacing wheat flour with $7.5 \%$ BRPP had higher mean rating scores of flavour than cake prepared with 2.5 and 5\% BRPP. On the other hand, there were no significant differences in compressibility between the control cake and cake prepared with 5 and 7.5\% BRPP but cake prepared with $2.5 \%$ of BRPP significantly decreased in compressibility compared to the control cake. These results are in agreement with the findings of Chauhan and Rajput (2018) who showed that cookies prepared with beet root pomace powder were acceptable on all sensory evaluation (flavour, texture, colour, aroma and overall acceptability). This indicates that the pomace produced from juice industries could be successfully used in the preparation of cake with high healthy benefits. This can be used as a modern functional food.

\section{CONCLUSION}

The obtained results indicated that beet root pomace powder possess antioxidant properties, which is a rich source of polyphenols, $\beta$ carotene, ascorbic acid and betalain, have hypoglycemic effects and mitigates of oxidative damage in renal tissues through improvement of antioxidants system in nephropathy diabetic rats. So, it is recommended to use beet root pomace as a functional food.

\section{REFERENCES}

Abdel-Monem, A., A. Fawkeya, and H. Rasha. 2014. Biological activity of the Egyptian medicinal plants: Part 3 Antioxidant, cytotoxicity, anti-diabetic activities and constituents of Beta vulgaris subsp. perennis. Indian Streams Res. J. 4(1): P1.

Abuelezz, S. A., N. Hendawy, and S. A. Gawad. 2016. Alleviation of renal mitochondrial dysfunction and apoptosis underlies the protective effect of sitagliptin in gentamicin-induced nephrotoxicity. J. Pharm. Pharmacol. 68: 523-532. 
Aebi, H. 1984. Catalase in vitro. Methods Enzymology. 105:121-126.

Allain, C.C. .1974. Enzymatic determination of total serum cholesterol. Clin. Chem. 20: 470-475.

Azab, E. A. and M. A. Algridi. 2017. Amelioration of gentamicin induced dyslipidemia in Guinea Pigs by Curcumin and Rosemary. Academic Research Publishing Group. Scientific Review. 3(2): 6-16.

Artimage, G.Y. and W.G. Berry. 1987. Statistical Methods 7th Ed. Ames, Iowa State University Press. 39-63.

Bala, L., S. Srivastava, Z. Siddiqi and T. Singh. 2019. Beetroot supplementation on non-alcoholic fatty liver disease patients. Curr Res. Nutr. Food Sci. J. 7(1): 96-101.

Burstein, M., H. R. Scholnick and R. Morfin. 1980. Rapid method for the isolation of lipoproteins from human serum by precipitation with polyanions. Scand J. Clin. Lab. Invest. 40: 583-595.

Čanadanović-Brunet, J. M., S. S. Savatović, G. S. Ćetković, J. J.Vulić, S. M. Djilas, S. L. Markov and D. D. Cvetković. 2011. Antioxidant and antimicrobial activities of beet root pomace extracts. Czech, J. Food Sci. 29(6):575-585.

Castellar, M. R., J. M. Obo'n, M. Alacid and J.A. Ferna'ndez-Lo'pez. 2003. Color properties and stability of betacyanins from Opuntia fruits. J. Agr. Food Chem. 51: 2772-2776.

Chauhan, S. and H. Rajput. 2018. Production of gluten free and high fiber cookies using beet root waste powder and wheat flour husk. The Pharma Innovation J. 7(11): 556-558.

Cordero-Herrera, M. M. Á., L. Goya, and S. Ramos. 2015. Cocoa intake ameliorates hepatic oxidative stress in young Zucker diabetic fatty rats. Food Research International. 69: 194-201.

Dontabhaktuni, A., D. R. Taft and M. Patel. 2016. Gentamicin renal excretion in rats: Probing strategies to mitigate drug-induced nephrotoxicity. Pharmacol, Pharm. 7: 43-55.

Doumas, B.T. 1975. Detremination of Total Proteins in Blood Serum. Clin Chim. Principles and Technics Harper ROW.N.Y. pp.182.

Drury, R. A. and E. A. Wallington. 1980. Carton's Histological Technique, 5th ed., Oxford Univ. London. U.K.

El-Gamal, A. A., M. S. Al-Said, M. Raish, M. Al-Sohaibani, S. M. Al-Massarani, A. Ahmad, M. Hefnawy, M. Al-Yahya, O. A. Basoudan and S. Rafatullah. 2014. Beetroot (Beta vulgaris, L.) extract ameliorates gentamicin-induced nephrotoxicity associated oxidative stress, inflammation and apoptosis in rodent model. Mediat Inflamm. 983-952.

Elizabeth, H. and M. D. Harris. 2005. Elevated liver function tests in type 2 diabetes. Clin Diabetes. 23: 115-119.

El-Kashef, D. H., A. E. El-kenawi, G. M. Suddek and H. A. Salem. 2015. Flavocoxid attenuates gentamicin-induced nephrotoxicity in rats. Naunyn-Schmiedeberg's Arch. Pharmacol. 388: 1305-1315.
Forbes, J. M. and M. E. Cooper. 2013. Mechanisms of diabetic complications. Physiol. Rev. 93: 137-188.

Fossati, P., L. Prencipe and G. Berti. 1980. Use of 3, 5-dichloro-2-hydroxybenzenesulfonic

acid/4-aminophenazone chromogenic system in direct enzymic assay of uric acid in serum and urine. Clinical Chemistry. 26 (2): 227-231.

Fossati, P. and I. Prencipe. 1982. Serum triglycerides determination colorimetrically with an enzyme that produce hydrogen peroxide. Clin. Chem. 28: 2077-2083.

Franke, A. A., L. J. Custer, C. Arakaki and S. P. Murphy. 2004. Vitamin C and flavonoid levels of fruits and vegetables consumed in Hawaii. Journal of Food Composition and Analysis. 17(1): 1-35.

Gezginci-Oktayoglu, S., O. Sacan, S. Bolkent, Y. Ipci, L. Kabasakal, G. Sener and R. Yanardag. 2014. Chard) Beta vulgaris, L. var. cicla) extract ameliorates hyperglycemia by increasing GLUT2 through Akt2 and antioxidant defense in the liver of rats. Acta Histochem. 116(1):32-39.

Haque, M., J. Islam, A. Rahaman, F. A. Selina, M. A. Rahman, M. Hasan and S. Hossain. 2014. Raphanus sativus ameliorates atherogenic lipid profiles in hypercholesterolemic rats and hypercholesterolemiaassociated peroxidative liver damage. $\mathrm{J}$ of Advances in Chemistry. 23: 1385-1394.

Hassan, S. K., N. M. El-Sammad, A. H. Abdel-Halim, A. M. Mamdouh Mousa, W. K. B. Khalil and N. Anwar. 2018. Flavonoids-rich Extract of Beta vulgaris Subsp. cicla L. var. Flavescens Leaf, a Promising Protector Against gentamicininduced nephrotoxicity and hepatotoxicity in rats. Int. J. Pharmacol. 14 (5): 652-666.

Hromi-Fiedler, A., D. Chapman, S. Segura-Pérez, G. Damio, P. Clark, J. Martinez and R. Pérez-Escamilla. 2016. Barriers and facilitators to improve fruit and vegetable intake among WIC-Eligible Pregnant Latinas: An Application of the Health Action Process Approach Framework. Journal of Nutrition Education and Behavior. 48 (7): 468-477.

Hugget, A. S. G. and D. A. Nixon .1957. Use of glucose, oxidase, peroxidase and O-dianisidine in the determination of blood glucose and urinary glucose. Lancet. 273: 366-370.

Huma, P., A. Bajpai, S. Bhatia and S. Singh. 2017. Analysis of biscuits enriched with fiber by incorporating carrot and beetroot pomace powder. The Indian Journal of Nutrition and Dietetics. 54 (4):403-413.

Indumathi, D., K. Sujithra, S. Srinivasan and V. Vinothkumar. 2017. Ameliorating effect of betanin, a natural chromoalkaloid by modulating hepatic carbohydrate metabolic enzyme activities and glycogen content in streptozotocin-nicotinamide induced experimental rats. Biomed Pharmaco. 88: 1069-1079.

Jain, D. and R. Somani. 2015. Silibinin: A bioactive flavanone in milk thistle ameliorates gentamicin induced nephrotoxicity in rats. Pharmacologia. 6: 38-44. 
Jeyanthi, T. and P. Subramanian. 2009. Nephroprotective effect of withania somnifera: a dose-dependent study, Renal Failure. 31 (9): 814-821.

Kahn, S. E., M. E. Cooper and S. Del Prato. 2014. Pathophysiology and treatment of type 2 diabetes: perspectives on the past, present, and future. Lancet. 383(9922):1068-1083.

Kamel, M. A., I. H. Abdel Fadil and M. A. Noha. 2015. Prevention of hepato-renal toxicity with vitamin E, vitamin $\mathrm{C}$ and their combination in gentamicin treated rats. Int. J. Pharm. Sci. 5: 1289-1296.

Kaškonienė, V., A. Maruška, O. Kornyšova, N. Charczun, M. Ligor and B. Buszewski. 2009. Quantitative and qualitative determination of phenolic compounds in honey. Chemine Technologija. 3 (52): 74-80.

Khalil, A. H. 1998. The influence of carbohydrate-based fat replacers with and without emulsifiers on the quality characteristics of lowfat cake. Plant Food Hum Nutr. 52: 299-313.

Kittell, F. 2012. Diabetes Management, In Thomas LK, Othersen JB. Nutrition Therapy for Chronic Kidney Disease. CRC. Press. p. 198.

Lee, R. and D. Nieman. 1996. Nutrition Assessment. 2nd Ed. Mosby, Missouri, USA. pp. 591-594.

Lefevre, G., L. F. Beljean, D. Beyerle, R. J. P. Bonnefont, P. T. Cristol and J. Torreilles. 1998. Evaluation of lipid peroxidation by measuring thiobarbituric acid reactive substances. Annales Biologie Clinique. 56: 305-319.

Lidder, S. and A. J. Webb. 2013. Vascular effects of dietary nitrate (as found in green leafy vegetables and beet root) via the nitrate-nitrite-nitric oxide pathway. British Journal of Clinical Pharmacology. 75: 677-696.

Liu, X., M. Zhao, J. Wang, B. Yang and Y. Jiang. 2008. Antioxidant activity of methanolic extract of emblica fruit (Phyllanthus emblica L.) from six regions in China. Journal of Food Composition and Analysis. 21(3): 219-228.

Lubrano, V. and S. Balzan. 2015. Enzymatic antioxidant system in vascular inflammation and coronary artery disease. World J. Exp. Med. 5(4): 218-224.

Makris, D. P., G. Boskou and N. K. Andrikopoulos. 2007. Polyphenolic content and in vitro antioxidant characteristics of wine industry and other agri-food solid waste extracts. Journal of Food Composition and Analysis. 20:125-132.

Masayasu, M. and Y. Hiroshi. 1979. Asimplified assay method of superoxide dismutase activity for clinical use. Clin. Chim. Acta. 92: 337-342.

Mazumdar, B. C. and K. Majumder. 2003. Methods on Physic-Chemical Analysis of Fruits. Univ. Cokkege of Agric. Calcutta. Univ. 108-109.

Murthy, K. N. C. and S. Manchali. 2012. Anti-diabetic potentials of red beet pigments and other constituents. In: Neelwarne B (ed) Red beet biotechnology: Food and pharmaceutical applications. Springer, New York, pp.155-174.
Nagata. M. and A. Yamashita. 1992. Simple method for simultaneous determination of chlorophyll and carotenoids in tomato fruit. J. Japan Soc. Food Sci. Technol. 39(10):925-928.

Nale, L. P., P. R. More, B. K. More, B. C. Ghumare, S. B. Shendre and C. S. More. 2012. Protective effect of Carica Papaya L. seed extract in gentamicin induced hepatotoxicity and nephrotoxicity in rats. Int. J. Pharm. Bio. Sci. (3): 508-515.

Necheles, T. F., T. A. Boles and D. M. Allen. 1968.Erthrocyte glutathione-peroxidase deficiency and hemolytic disease of the newborn infant. J. Pediatr. 72: 319-324.

Olumese, F. E. and H. A. Oboh. 2017. Toxicity study of beetroot (Beta vulgaris) extract in normal Sprague Dawley rats. NISEB, J. 17( 3): 125-133.

Omolaoye, T. S., T. Bongekile, S. S. Skosana and D. Plessis. 2018. Diabetes mellitus-induction: Effect of different streptozotocin doses on male reproductive parameters. Acta, Histochemica. 120: 103-109.

Palm, C. A., G. Segev, L. D. Cowgill, B. E. Leroy, K. L. Kowalkowski, K. Kanakubo and J. L. Westropp. 2016. Urinary neutrophil gelatinase-associated lipocalin as a marker for identification of acute kidney injury and recovery in dogs with gentamicin-induced nephrotoxicity. J. Vet. Internal Med. 30: 200-205.

Panda, S. and A. Kar. 2007. Apigenin (4 $\varnothing$,5,7-trihydroxy flavone) regulates hyperglycaemia, thyroid dysfunction and lipid peroxidation in alloxan-induced diabetic mice. Journal of Pharmacy and Pharmacology. 59(11): 1543-1548.

Panghal, A., K. Virkar, V. Kumar, S. B. Dhull, Y. Gat and N. Chhikara. 2017. Development of probiotic beetroot drink. current research in Nutrition and Food Science Journal. 5. Pharmacy. 2: 83-86.

Pereira, D., M. R. Paula and P. F. Raquel. 2013. Analysis of the physical-chemical and sensorial properties of Maria type cookies. Acta Chimica Slovace. 6(2): 269-280.

Philip, D.M. 1994. Clinical chemistry in diagnosis and treatment. 6th Ed., London. New York. New Delhi.

Rajashekar, V., E. U. Rao and P. Srinivas. 2012. Biological activities and medicinal properties of gokhru (Pedalium murex L.) Asian Pac. J. Trop. Biomed. 2: 581-585.

Reeves, P. G., F. H. Nielsen and G. C. Fahey. 1993. AIN-93 purified diets for laboratory rodents: Final report of the American Institute of Nutrition ad Hoc Writing Committee on the reformulation of the AIN-76A rodent diet. J. Nutr. 123: 1939-1951.

Rojas, E., A. L. Herrera, L. A. Poirier and P. Ostrosky-Wegman. 1999. Are metal Dietary carcinogens? Mutat. Res. 44: 157-181.

Sacan, O. and R. Yanardag. 2010. Antioxidant and antiacetylcholine sterase activities of chard (Beta vulgaris L. var. cicla). Food Chem Toxicol. 48(5): 1275-1280.

Saddala, R. R., L. Thopireddy, N. Ganapathi and S. R. Kesireddy. 2013. Regulation of cardiac oxidative stress and lipid peroxidation in streptozotocin-induced diabetic 
rats treated with aqueous extract of Pimpinella tirupatiensis tuberous root. Exp. Toxicol. Pathology. 65: 15-19.

Sardi, E., E. Stefanovits-Banyai, I. Kocsis, M. T. Akacs-Hajos, H. Febel and A. Blazovics. 2009. Effect of bioactive compounds of table beet cultivars on alimentary induced fatty livers of rats. Acta Alimentaria. 38(3): 267-280.

Singh, A., S. Verma, V. Singh, C. Jappa, N. Roopa and P. Raju. 2015. Beet root juice supplementation increases high density lipoprotein-cholesterol and reduces oxidative stress in physically active individuals. Journal of Pharmacy and Nutrition Sciences. 5(3):179-185.

Sodimbaku, V., L. Pujari, R. Mullangi and S. Marri. 2016. Carrot (Daucus carota L.): Nephroprotective against gentamicin-induced nephrotoxicity in rats. Indian $\mathrm{J}$. Pharmacol. 48: 122-127.

Sudha, M. L., V. Baskaran and K. Leelavathi.2007. Apple pomace as a source of dietary fiber and polyphenols and its effect on the rheological characteristics and cake making. . Food Chemistry, 104: 686-692.

Tan, D., Y. Wand, B. Bai, X. Yang and J. Han. 2015. Betanin attenuates oxidative stress and inflammatory reaction in kidney of paraquat-treated rat, Food Chem. Toxicol. 78: 141-146.

Tietz, N. 1986. Textbook of Clinical Chemistry, WB Saunders, Philadelphia, Pa, USA.

Tietz, N. M. 1994. Fundamentals of Clinical Chemistry. 2 nd Edn WB Saunders, Philadelphia. pp: 692.

Trinder, P. 1969. Determination of blood glucose using an oxide seperoxidase system with a non-carcinogenic chromogen. Journal of Clinical Pathology. 22 (2): 158-161.

Ul-Kabir, A., M. B. Samad, A. Ahmed, M. R. Jahan, F. Akhter, J. Tasnim, S. M. Hasan, S. S. Sayfe and J. M. Hannan. 2015. Aqueous fraction of Beta vulgaris ameliorates hyperglycemia in diabetic mice due to enhanced glucose stimulated insulin secretion, mediated by acetylcho-line and GLP-1, and elevated glucose uptake via increased membrane bound GLUT4 transporters. PLoS One. 10(2): e0116546.
Váli, L., B. E. Stefanovits, K. Szentmihalyi, H. Febel, E. Sardi, A. Lugasi,I. Kocsis and A.Blazovics. 2007. Liver-protecting effects of table beet (Beta vulgaris var. Rubra) during ischemia reperfusion. Nutrition. 23(2): 172-178.

Vulic', J., J. C`anadanovic'-Brunet, G. C'etkovic', V. Tumbas, S. Djilas, D. C'etojevic'-Simin and V. C`anadanovic'. 2012. Antioxidant and cell growth activities of beetroot pomace extracts. Journal of Functional Foods. 4: 670-678.

Vulic, J. J., T. N.Cebovic, J. M.Canadanovic'-Brunet, G. S.Cetkovic', V. M.Canadanovic, S. M. Djilas, V. T.Tumbas Šaponjac. 2014. In vivo and in vitro antioxidant effects of beetroot pomace extracts. J. Functional Foods. 6: 168-175.

Wei, M., L. Ong, M. T.Smith, F. B.Ross, K.Schmid, A. J.Hoey, D. Burstow and L. Brown. 2003. The streptozotocin-diabetic rat as a model of the chronic complications of human diabetes. Heart Lung Circ. 12 (1): 44-50.

World Health Organization. 2016. Definition and diagnosis of diabetes mellitus and intermediate hyperglycaemia: http:// whqlibdoc. Who.int/ publications/ 2006/ 9241594934-eng. Pdf (accessed 21 January 2016).

Wootton-Beard, P.C., A. Moran and L. Ryan. 2011. Stability of the total antioxidant capacity and total polyphenol content of 23 commercially available vegetable juices before and after in vitro digestion measured by FRAP, DPPH, ABTS and Folin-Ciocalteu methods. Food, Res. Int. 44: 217-224.

Wroblewska, M., J. Juskiewicz, and W. Wiczkowski. 2011. Physiological properties of beetroot crisps applied in standard and dyslipidaemic diets of rats: Lipids in Health and Disease. 10(178):18.

Xu, X., N. Zheng, Z.Chen, W.Huang, T.Liang and H.Kuang. 2016. Puerarin, isolated from Pueraria lobata (Willd.), protects against diabetic nephropathy by attenuating oxidative stress. Gene. 591:411-416. doi:10.1016/j.gene.2016.06.032.

Yanardağ, R., S.Bolkent, O. Karabulul-Bulan and S. Tunali. 2003. Effects of vanadyl sulfate on kidney in experimental diabetes. Biol. Trace. Elem. Res. 95:73-85.

Yang, B., J. S. Wang and M. M.Zhao. 2006. Identification of polysaccharides from pericarp tissues of litchi (Litchi chinensis Sonn.) fruit in relation to their antioxidant activities. Carbohydr. Res. 341: 634-638. 


\section{الملخص العربي}

التأثيرات العلاجية المحتملة لمخلفات جذور البنجر على الفئران المصابة باعتلال الكلى والسكرى نجلاء على الثيخ ، أمل ناصف زكى ناصف و نفيسة ياسر عثمان

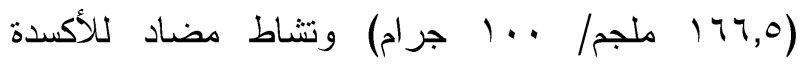

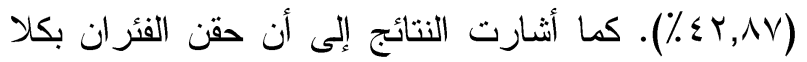
من الستربتوزوتوسين والجنتاميسين أدى إلى ارتفاع في مستويات كلا من السكر في الدم والبول، صورة دهون الدم، وظائف الكلى يالسيرم و المالونالدهيد مع انخفاض في نشاط الجلوتاثيون بيروكسيد، السوبر أوكسيديز و الكتاليز في وطي

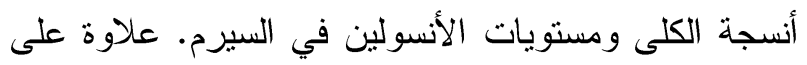
ذللك فقد أظهرت النتائج أن تغذية الفئران المصابة بإعتلال الكلى والسكري على نظام غذائي يومي يحتوي على مسحوق مخلفات جذور البنجر بنسبة ه و ٪,0\% لمدة . يومًا أدى إلى انخفاض ملحوظ في مستويات الجلوكوز يالدم و البول، دهون الدم ووظائف الكلى بالسيرم ومستويات المالونالدهيد مصحوبا بارتفاع فى نشاط كلا من الجلوتاثيون

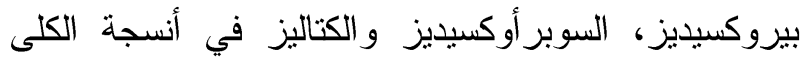
ومستويات الأنسولين في السيرم مقارنة بالمجموعة الضابطة الموجبة، في حين أن تغذية الفئران على وجبة تحتوى على V,O \% من مسحوق مخلفات جذور البنجر

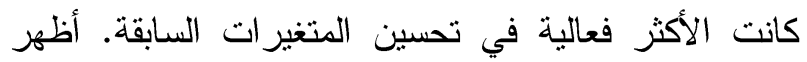
التقييم الحسي للكيك المحضر بـ ٪,0 من مسحوق

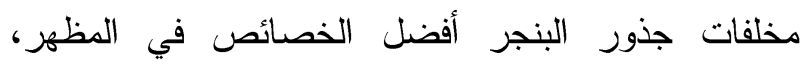
الطعم، الملمس، الانضغاط، اللون والقبول العام مقارنة

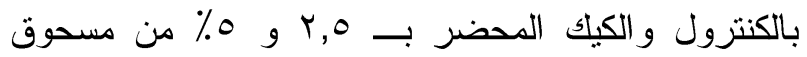
مخلفات جذور البنجر • وقد خلصت الدراسة إلى أن مسحوق مخلفات جذور البنجر لله تأثثرات قوية لخفض السكر في الام ويحسن التدمير الكلوي الناجم عن الجنتاميسين في الفئران المصابة بالسكري. لذا نوصى بإضافة مسحوق مخلفات جذور البنجر إلى منتجات المخابز وتستهلك يوميًا لمرضى الكلى.
تستخدم جذور البنجر على نطاق واسع في العديد من الأطباق التقليدية، حيث أن استهلاكه يحقق العديد من المنافع الصحية و العلاجية العالية لجسم الإنسان، و التى تعزى إلى الى محتواه العالي من المركبات الكيميائية الفعالة وخصائصه المضادة للأكسدة. الهدف من هذه الار اسة هوتقييم التاثير ات العلاجية المحتملة لمسحوق مخلفات جذور البنجر على اعتلال الكلي الناجم عن الحقن بالجنتاميسين في الفئران المصابة بالسكري وتطبيقاته في الكيك. قسمت ثلاثون من ذكور الفئران البالغة البيضاء عشوائيا إلى مجموعتين رئيسيتين وتم تغذيتهم علي الوجبة القياسية. المجموعة الأولى هى المجموعة الضابطة السالبة( آفئر ان) و المجموعة الثانية هي مجموعة الفئران المصابة باعتلال الكلى في

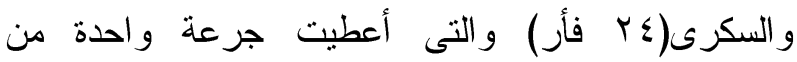
الستربتوزوتوسين (STZ)عن طريق الحقن داخل البريتون مقدارها 7 ملجم / كجم من وزن الجسم.، ثم بعد ذللك

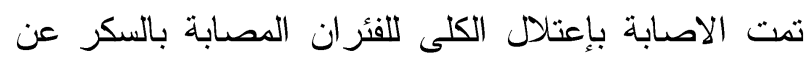

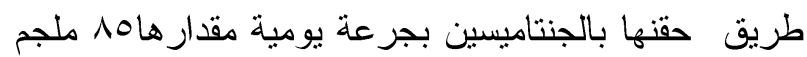
/ كجم من وزن الجسم لمدة ^ أيام متتالية. وقسمت

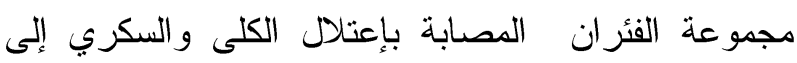
أربع مجموعات فرعية (T فئران بكل منها) على النحو التالي: المجموعة الأولى هى المجموعة الضابطة الموجبة و المجموعات الثانية ،الثالثة و الر ابعة تتاولت الوجبة القياسية

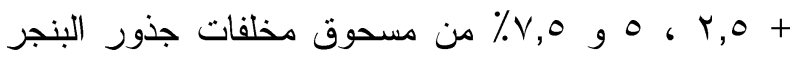

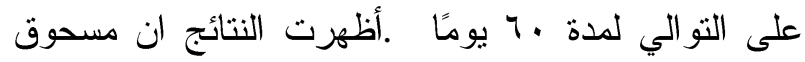
مخلفات جذور البنجر يحتوي على فينو لات كلية (Y, T ( ملجم حامض جاليك / · . (جر ام)، فلافونيدات ( r, اس ملجم

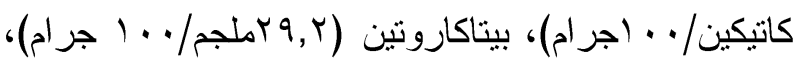

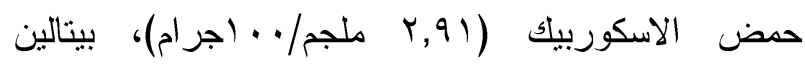

